\title{
Impact of Naphthalene Acetic Acid and Gibberellic Acid on Growth and Yield of Capsicum, Capsicum annum (L.) cv. Indra under Shade Net Conditions
}

\author{
Prateek Singh $^{1}$, Devi Singh ${ }^{1}$, Deepak Kumar Jaiswal ${ }^{2} *$, D.K. Singh ${ }^{3}$ and Vaibhav Singh ${ }^{4}$ \\ ${ }^{1}$ Department of Horticulture, SHIATS, Allahabad, India \\ ${ }^{2}$ Department of Entomology and Agricultural Zoology, BHU, Varanasi, India \\ ${ }^{3}$ Department of Genetics and Plant Breeding, BHU, Varanasi, India \\ ${ }^{4}$ Department of Horticulture, BHU, Varanasi, India \\ *Corresponding author
}

\begin{tabular}{|c|c|}
\hline & A B S T R A C T \\
\hline $\begin{array}{l}\text { Capsicum, NAA, } \\
\text { GA3, Growth, } \\
\text { Yield, Shade net } \\
\text { condition. }\end{array}$ & \multirow{3}{*}{$\begin{array}{l}\text { The present investigation entitled "Study on Naphthalene acetic acid and Gibberellic acid } \\
\text { on growth and yield of Capsicum, Capsicum annum (L.) cv. Indra under shade net } \\
\text { condition" was carried out at the vegetable research farm of the Department of } \\
\text { Horticulture, Sam Higginbottom Institute of Agriculture, Technology and Sciences } \\
\text { (Deemed to-be University), Allahabad during the Rabi season of 2014-2015, the } \\
\text { experiment was laid out in Randomized Block Design having } 9 \text { treatments with } 3 \\
\text { replications. The experiment revealed that NAA @ } 60 \mathrm{ppm} \text { increased plant height } \\
\text { (120.59cm), number of branches }(16.05) \text {, plant spread }(92.57 \mathrm{~cm}) \text {, days to first flowering } \\
\text { (32.51), number of flower per plants }(11.83) \text {, fruit weight }(169.66 \mathrm{~g} \text { ), no of fruit per plant } \\
\text { (9.87), no of seeds per fruit }(110.78) \text {, fruit yield per plant }(1.67 \mathrm{~kg} \text { ), fruit yield per plot } \\
\text { (15.07kg), fruit yield per hectare (69.76t), With the above result it can be concluded that } \\
\text { NAA @ } 60 \mathrm{ppm} \text { is very much beneficial for the growth and yield of capsicum. }\end{array}$} \\
\hline Article I & \\
\hline $\begin{array}{l}\text { Accepted: } \\
\text { 29 May } 2017 \\
\text { Available Online: } \\
\text { 10 June } 2017\end{array}$ & \\
\hline
\end{tabular}

\section{Introduction}

Vegetables play an important role in nutritional security, economic viability and fit well into the predominant intensive cropping systems prevailing in different parts of our country. More than 60 kinds of vegetables are grown in India in tropical, subtropical and temperate agro-climates. Olericulture is an important horticulture sector, occupying an area of 9.20 million ha during 2012-13 with a total production of 162.2 million tones and having average productivity of 17.6 tones/ha. In fact vegetables constitute about $61 \%$ of horticulture production. Bell pepper (Capsicum annuum L.) belongs to the family
Solanaceae under the genus Capsicum (Shoemaker and Taskey, 1995). The crop is a native of Tropical South America especially Brazil which is thought to be the original home of peppers (Islam et al., 2010). It is also used in salad and soup preparation. It is rich in vitamin A (180 IU) and vitamin C than that of tomatoes. From every 100 gram of edible portion of capsicum $24 \mathrm{k}$ cal of energy, $1.3 \mathrm{~g}$ of protein, $4.3 \mathrm{~g}$ of carbohydrate and $0.3 \mathrm{~g}$ of fat is provided. It has attained a status of high value crop in India in the recent years and occupies a pride place among vegetables in Indian cuisine, because of its delicate taste 
and pleasant flavor coupled with rich content of ascorbic acid and other vitamins and minerals. The mature-fruits (green, red and yellow) of sweet pepper are eaten raw or widely used in stuffing's, baking's, pizza and burger preparations.

Plant growth regulators are considered as new generation of agro-chemicals after fertilizers, pesticides and herbicides to augment yield and quality. The plant growth regulators are known to enhance and stimulate the translocation of photo assimilates thereby helping in better retention of flowers and fruits. Besides this, the growth regulators have the ability to cause accelerated growth in plants. The growth regulators or promoters like GA3 and NAA stimulate vegetative growth and are involved in the initiation of cell division in the cambium. These plant growth regulators cause osmotic uptake of water which maintain a swelling force against the softening of cell wall (Arora et al., 1985).

\section{Materials and Methods}

The present investigation was conducted from October 2014 -May 2015 at the experimental field of the Department of Horticulture, Sam Higginbottom Institute of Agriculture, Technology and Sciences, Allahabad. The experiment was laid out in a Randomized Block Design with 9 treatments and 3 replications at a spacing of $60 \times 40 \mathrm{~cm}$ at the time transplanting, The experimental site is located at a latitude of $20^{\circ}$ and $15^{\circ}$ North and longitude of $60^{\circ}$ East and at an altitude of 98 meters above mean sea level (MSL) and variety selected for research was Indra (collected from I.A.R.I., New Delhi). The growth regulator (promoters) solutions were prepared as per the requirement i.e. $1 \mathrm{ml}$ of growth regulator (promoters) in 10 liters of water gives $100 \mathrm{ppm}$. The prepared solutions were sprayed at two stages i.e., at pre bloom and fruit development stage. Five plants were taken for recording observations. The recommended package of practices was followed for raising the successful crop. Data on plant growth and yield characters were recorded seven months after transplanting when the plants were fully grown. The treatments of the present experiment were $T_{0}$ - control, $\mathrm{T}_{1}-\mathrm{GA}_{3} 30 \mathrm{ppm}, \mathrm{T}_{2}-\mathrm{GA}_{3} 60 \mathrm{ppm}$, $\mathrm{T}_{3}-\mathrm{GA}_{3}$ 80ppm, $\mathrm{T}_{4}-\mathrm{GA}_{3}$ 100ppm, $\mathrm{T}_{5}$ - NAA 30ppm, $\mathrm{T}_{6}-\mathrm{NAA} 40 \mathrm{ppm}, \mathrm{T}_{7}-\mathrm{NAA} 60 \mathrm{ppm}$ and $\mathrm{T}_{8}-\mathrm{NAA} 100 \mathrm{ppm}$.

\section{Results and Discussion}

The outcome of the investigations for growth parameters like plant height $(\mathrm{cm})$, plant spread $(\mathrm{cm})$, no. of branches, days to first flowering, no. of flowers per plant, have been presented in table 1 and for yield parameters like fruit weight $(\mathrm{g})$, no. of fruits per plant, no. of seeds per fruit, fruit yield per plant $(\mathrm{kg})$, fruit yield per plot $(\mathrm{kg})$ and fruit yield per hectare $(\mathrm{t})$ in table 2. From the experiment, it was revealed that the maximum plant height $(120.59 \mathrm{~cm})$, maximum plant spread $(92.57 \mathrm{~cm})$, maximum no of branches $(16.05)$, minimum number of days to first flowering (32.51), maximum no of flower per plant (11.83), maximum fruit weight (169.66 g), maximum no of fruits per plant (9.87), maximum no of seeds per fruit (110.78), maximum fruit yield per plant $(1.67 \mathrm{~kg})$, maximum fruit yield per plot $(15.07 \mathrm{~kg})$ and maximum fruit yield per hectare $(69.76 \mathrm{t})$ was found in treatment $\mathrm{T}_{7}$ (NAA $\left.60 \mathrm{ppm}\right)$.

The treatment $\left(\mathrm{T}_{7}\right)$ was followed by $\mathrm{T}_{5}$ (NAA $30 \mathrm{ppm})$ for higher plant height $(109.38 \mathrm{~cm})$, plant spread $(87.10 \mathrm{~cm})$, no. of branches (13.56), no of flowers per plant (10.10), fruit weight $(168.26 \mathrm{~g})$, no. of fruits per plant (8.41), no. of seeds per fruit (105.26), fruit yield per plant $(1.41 \mathrm{~kg})$, fruit yield per plot $(12.72 \mathrm{~kg})$ and fruit yield per hectare (58.96 t), while, the lowest number of days to first flowering was observed in $T_{1}\left(G_{3}\right.$ $30 \mathrm{ppm}$ ) after $\mathrm{T}_{7}$. 
Table.1 Role of different growth regulators on growth parameters of capsicum

\begin{tabular}{|c|c|c|c|c|c|c|}
\hline Treatment & & & th Paramete & & & \\
\hline & & $\begin{array}{c}\text { Plant height } \\
(\mathrm{cm}) \\
120 \text { DAT }\end{array}$ & $\begin{array}{c}\text { Plant spread } \\
\text { (cm) } \\
\text { 120 DAT }\end{array}$ & $\begin{array}{c}\text { Number } \\
\text { of branches } \\
120 \text { DAT }\end{array}$ & $\begin{array}{c}\text { Days to first } \\
\text { flower }\end{array}$ & $\begin{array}{c}\text { Number of } \\
\text { flowers/plant }\end{array}$ \\
\hline $\mathrm{T}_{0}$ & Control & 85.28 & 78.02 & 9.85 & 38.43 & 7.09 \\
\hline $\mathrm{T}_{1}$ & $\mathrm{GA}_{3} 30 \mathrm{ppm}$ & 103.49 & 85.64 & 11.99 & 33.14 & 8.87 \\
\hline $\mathrm{T}_{2}$ & $\mathrm{GA}_{3} 60 \mathrm{ppm}$ & 99.85 & 83.41 & 11.14 & 37.11 & 7.93 \\
\hline $\mathrm{T}_{3}$ & $\mathrm{GA}_{3} 80 \mathrm{ppm}$ & 88.07 & 76.36 & 11.72 & 37.72 & 7.73 \\
\hline $\mathrm{T}_{4}$ & $\mathrm{GA}_{3} 100 \mathrm{ppm}$ & 85.62 & 74.85 & 10.08 & 39.54 & 6.71 \\
\hline $\mathrm{T}_{5}$ & NAA 30 ppm & 109.38 & 87.10 & 13.56 & 34.88 & 10.10 \\
\hline $\mathrm{T}_{6}$ & NAA 40 ppm & 94.04 & 81.34 & 10.99 & 35.81 & 8.16 \\
\hline $\mathrm{T}_{7}$ & NAA 60 ppm & 120.59 & 92.57 & 16.05 & 32.51 & 11.83 \\
\hline $\mathrm{T}_{8}$ & NAA 100 ppm & 90.83 & 72.60 & 10.70 & 40.10 & 6.36 \\
\hline F Test & & $\mathbf{S}$ & $\mathbf{S}$ & $\mathbf{S}$ & $\mathbf{S}$ & $\mathbf{S}$ \\
\hline $\mathrm{CD}$ at $5 \%$ & & 1.13 & 3.25 & 0.26 & 0.46 & 0.27 \\
\hline
\end{tabular}


Table.2 Role of different growth regulators on yield parameters of capsicum

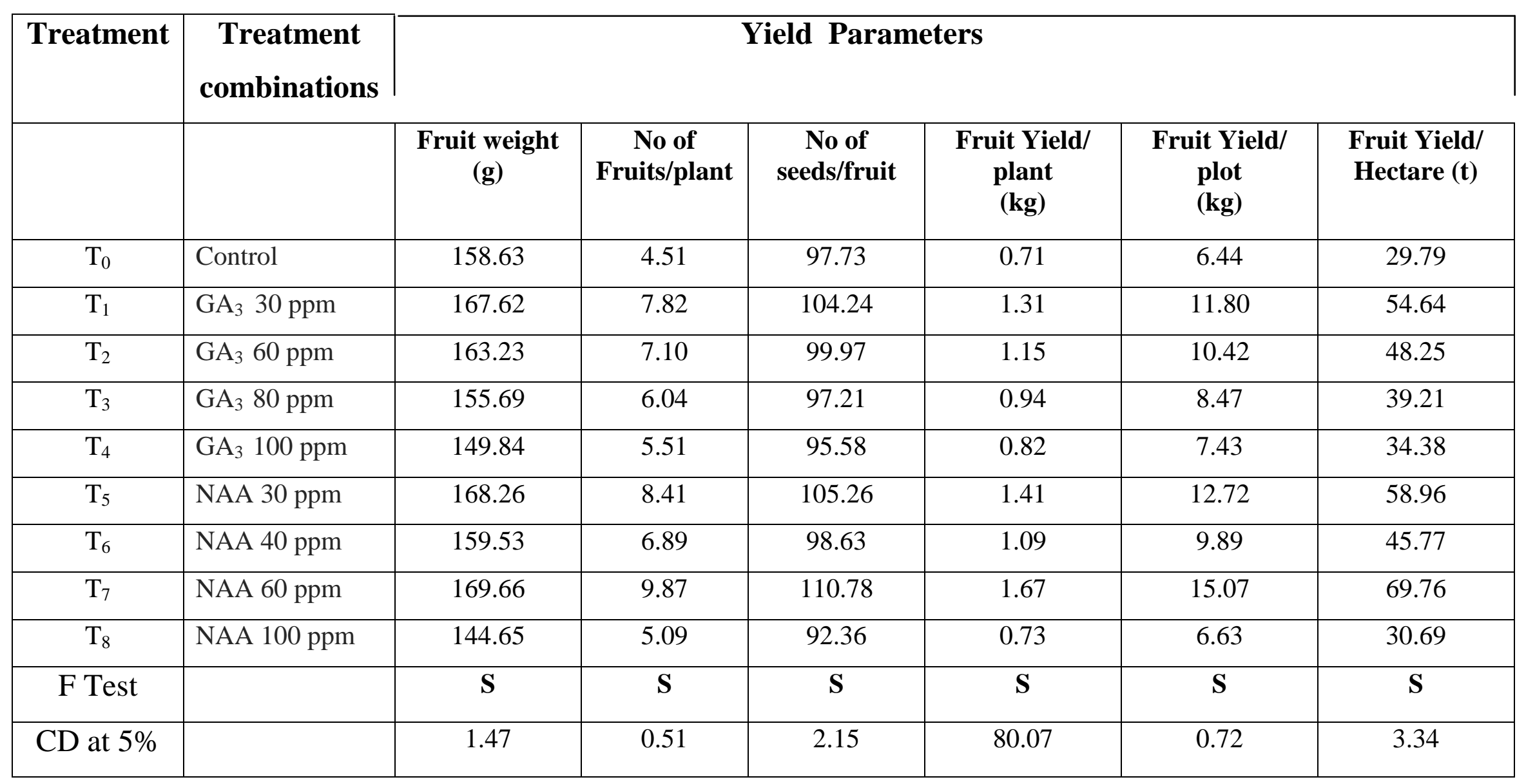


The lowest plant spread $(72.60 \mathrm{~cm})$, no. of flowers per plant (6.36), fruit weight (144.65 g) and no. of seeds per fruit (92.36) were observed in the treatment $\mathrm{T}_{8}$ (NAA 100ppm) while minimum plant height (85.28), number of branches per plant (9.85), no of fruits per plant(4.51), fruit yield per plant $(0.70 \mathrm{~kg})$, fruit yield per plot $(6.44 \mathrm{~kg})$ and fruit yield per hectare $(29.79 \mathrm{t})$ were recorded in the treatment $\mathrm{T}_{0}$ (Control) and maximum no. of days to first flowering was found in $\mathrm{T}_{8}$ (NAA $100 \mathrm{ppm})$. These results are similar to findings of Rana and singh (2012) for plant height in capsicum, Singh et al., (2012) for no. of branches in capsicum, Kannan et al., (2009) for first flowering in paprika, Shetty and Manohar (2008) for number of flowers per plant, Sridar et al., (2009), Tirakannanavar et al., (2009) for no. of fruits per plant in paprika chilli and Balraj et al., (2002) for yield of fruit per plant in chilli.

The treatment $\left(\mathrm{T}_{7}\right)$ was followed by $\mathrm{T}_{5}$ (NAA $30 \mathrm{ppm})$ for higher plant height $(109.38 \mathrm{~cm})$, plant spread $(87.10 \mathrm{~cm})$, no. of branches (13.56), no of flowers per plant (10.10), fruit weight $(168.26 \mathrm{~g})$, no. of fruits per plant (8.41), no. of seeds per fruit (105.26), fruit yield per plant $(1.41 \mathrm{~kg})$, fruit yield per plot $(12.72 \mathrm{~kg})$ and fruit yield per hectare $(58.96 \mathrm{t})$ while, the lowest number of days to first flowering was observed in $\mathrm{T}_{1}\left(\mathrm{GA}_{3}\right.$ $30 \mathrm{ppm}$ ) after $\mathrm{T}_{7}$. The lowest plant spread $(72.60 \mathrm{~cm})$, no. of flowers per plant $(6.36)$, fruit weight $(144.65 \mathrm{~g})$ and no. of seeds per fruit (92.36) were observed in the treatment $\mathrm{T}_{8}$ (NAA 100ppm) while minimum plant height (85.28), number of branches per plant (9.85), no of fruits per plant(4.51), fruit yield per plant $(0.70 \mathrm{~kg})$, fruit yield per plot $(6.44$ $\mathrm{kg})$ and fruit yield per hectare $(29.79 \mathrm{t})$ were recorded in the treatment $\mathrm{T}_{0}$ (Control) and maximum no. of days to first flowering was found in $\mathrm{T}_{8}$ (NAA 100ppm). These results are similar to findings of Rana and singh (2012) for plant height in capsicum, Singh et al.,
(2012) for no. of branches in capsicum, Kannan et al., (2009) for first flowering in paprika, Shetty and Manohar (2008) for number of flowers per plant, Sridar et al., (2009), Tirakannanavar et al., (2009) for no. of fruits per plant in paprika chilli and Balraj et al., (2002) for yield of fruit per plant in chilli.

\section{Economics}

The highest gross returns, net returns and cost benefit ratio (Rs. 1255680/ha, Rs. 901439/ha and 3.54:1) was significantly observed in $T_{7}$ (NAA $60 \mathrm{ppm}$ ) followed by (Rs. 1061280/ha, Rs. 707850/ha and 3.00:1) T (NAA 300ppm). Based on the results obtained in this experiment, it is concluded that the treatment concentration $\mathrm{T}_{7}$ (NAA $60 \mathrm{ppm}$ ) was found to be superior over all other treatments in relation to growth and yield parameters in capsicum under the agro-climatic conditions of Allahabad. However, since these results are based on one year experiment, further trials may be needed to substantiate the results.

\section{Acknowledgement}

Authors wish to acknowledge Dr. Devi Singh, Assistant Professor, Department of Horticulture, Sam Higginbottom Institute of Agriculture, Technology and Sciences, Allahabad and Dr. V. M. Prasad, Professor and head, Sam Higginbottom Institute of Agriculture, Technology and Sciences, Allahabad for their support to carry out this work.

\section{References}

Arora,S.K., Pandita, M.L., Baswana, K.S., 1985. Effect of growth regulators on flowering and fruiting of bottle gourd. Haryana Agrculture University Journal and Research. 25(1), 36-41. 
Balraj R., Kurdikeri M.B., Revanappa., 2002. Effect of growth regulators on growth and yield of chilli (Capsicum annuum) at different pickings. Indian Journal of Horticulture. 59(1), 84-88.

Islam, M., Saha, S., Akand., Rahim., 2010. A. Effect of sowing date on the growth and yield of sweet pepper (Capsicum annuum L.). Agronomski Glasnik., $1 / 2010$.

Kannan, K., Jawaharlal, M., Prabhu, M., 2009. Effect of plant growth regulators on growth and yield parameters of paprika cv.ktpl-19. Agriculture Science Digest. 29 (3), 157-162.

Pundir, J. P. S., Yadav, P.K., 2001. Note on effect of GA3, NAA and 2, 4-D on growth, yield and quality of tomato var, Punjab Chhuhara. Current Agriculture. 25(1/2), 137-138.

Rana, N.R., Singh D.K., 2012. Influence of bio regulators on quantitative and qualitative and ualitative parameters of sweet pepper under controlled condition. Progressive Horticulture. 44(1), 96-100.

Sridhar, Gutam., Koti, R. V., Chetti, M. B., Hiremath, S. M., 2009. Effect of naphthalene acetic acid and mepiquat chloride on physiological components of yield in bell pepper (capsicum аппиит L.). Indian journal of agriculture Research. 47(1).

Shoemaker, J. S., Taskey, B. J. E., 1995. Practical Horticulture. John Wiley and Sons Incorporation, New York.

Shetty G. R., Manohar, R, K., 2008. Influence of pruning and growth regulators on flowering, fruit set and yield of coloured capsicum (Capsicum anпиит L.) cv. Orobelle under naturally ventilated greenhouse. Asian Journal of Horticulture. 3(2), 13-216.

Singh, R N., Pal, S.L., Rana. D.k., Rawat, S.S., Gusain, M.S., 2012. Effect of Bioregulators on growth and yield parameter of capsicum cultivars under controlled condition. HortFlora Research Spectrum. 1(1), 50-54.

Tirakannanavar, Shantappa, Ahmed, Ao M. S., Munikrishnappa, P. M., Mukesh Chavan, L, MastikolL A B., 2009. Effect of plant growth regulators and method of application on growth, fruit, and seed yield in paprika chilli. Indian Seed Research. 37(1/2), 14-19.

\section{How to cite this article:}

Prateek Singh, Devi Singh, Deepak Kumar Jaiswal, D.K. Singh and Vaibhav Singh. 2017. Impact of Naphthalene Acetic Acid and Gibberellic Acid on Growth and Yield of Capsicum, Capsicum annum (L.) cv. Indra under Shade Net Conditions. Int.J.Curr.Microbiol.App.Sci. 6(6): 2457-2462. doi: https://doi.org/10.20546/ijcmas.2017.606.291 